\title{
Analysis on UK Robotics and Autonomous Systems Research Development
}

\author{
Wang Xiaodi; Xiao Xue; Zhang Xiaojing; Meng Jie \\ Beijing Institute of Science and Technology \\ Beijing, China \\ wangxd@bjstinfo.com.cn
}

\begin{abstract}
The development of robot technology change rapidly, computer systems, machine learning, artificial intelligence system, automation technology, automatic car, health and technology resources, networking will quickly change the human social and economic life. Robotics is not only the key support equipment of advanced manufacturing industry, but also an important entry point to improve human lifeway. Whether industrial robots application in manufacturing environment, or service-oriented robots applied in non-manufacturing environment, the research, development and industrialization is an important indicator of national science and technology innovation and high-end manufacturing level. The paper briefly introduces research and development architecture, development strategy, and key application fields in the UK. The article summarizes future development trend and the main research results of UK RAS, and it is discussed existing issues and future development direction. On this basis, the paper analyzes issues in robotics development in China and put forward some corresponding suggestions.
\end{abstract}

Keywords-Robotics and autonomous systems (RAS); UK; Research and development; Strategic distribution

\section{INTRODUCTION}

In March 2016, the Price Waterhouse Coopers (PWC) released a research report "Redefining Business Success in a Changing World the 19th Annual Global CEO Survey" [1]. The report pointed out 8 decisions emerging core technology in the futurewhich included robotics, unmanned aerial vehicle (UAV) technology. Robotics and autonomous systems (RAS) technology, information technology and digital technique are known as manufacturing cutting-edge technology. It is the inevitable trend and future direction of advanced manufacturing industry development. Moreover, McKinsey Global Institute predicts that half of today's work activities could be automated by 2055 . It follows that robotics industry will serve as an important symbol of a country's science and technology innovation and high-end manufacturing level. RAS is one of eight core technologies identified by UK's government as a national developing strategy. It is also the most important industry strategy potential field to promote economic growth [2].

\section{A. Robotics and autonomous systems (RAS) development strategy}

In July 2016, the UK government announced the first official robotics strategy "RAS2020", which was collaborated on the planning and execution of the Robotics and Autonomous Systems (RAS) strategy by academia and government. Moreover, it provided financial support to ensure UK robotics industry to leading global competition race.

The government's Technology Strategy Board has been granted $\$ 685$ million for the next year's technology development funds, and $\$ 257 \mathrm{M}$ million of which has been allocated for jumpstarting UK RAS development plan. The UK government hoped through the RAS 2020 strategy, it would be able to garner a $10 \%$ share of global robotics market by 2025 , which would be estimated $\$ 120$ billion [7].

The strategy recommendations are following:

- Invest further in the five RAS strategy strands: coordination, assets, challenges, clusters and skills to build the UK's RAS capability.

- Establish the means for funding agencies to formally work together in execution, so that ideas, people and activity flow readily from basic investigation through early stage demonstration to fully trialed commercial product.

- Establish a RAS Leadership Council to engage with senior leaders across a range of sectors in industry, academia and Government, providing independent advisory oversight of planning and execution of the strategy.

- Establish a RAS Leadership Council to engage with senior leaders across a range of sectors in industry, academia and Government, providing independent advisory oversight of planning and execution of the strategy.

- Continue to consult widely on potential Assets and cross sector Grand Challenges.

- Continue to develop dialogue with those involved in standards and regulation to develop more detailed thinking. 
- Extend outreach and public engagement activities to continue changing public perceptions and improve understanding of public concerns.

- Articulate to businesses and investors internationally (e.g. through UKTI) that the UK aims to be the best place to invest in taking RAS technologies to market.

\section{UK-RAS NETWORK DEVELOPMENT STRATEGIC LAYOUT}

The Engineering and Physical Sciences Research Council (EPSRC) is a non-government funded agency which is under the British Research Council (RCUK), and it was created in 1994 by Department for Business, Innovation and Skills and
Research Councils UK. The purposes of this British research council are: (1) Promote and support high quality basic, strategic and applied research in engineering and natural sciences and related education. (2) Improve knowledge and technology development and provide scientists and engineers training. (3) Responsible for knowledge popularization and public consultation in engineering fields (Mathematics, Robotics and Computer Science). (4) Improve research, training and innovation of engineering and physical science.

Since the UK government released RAS2020 strategic plan in 2016, the government will vigorously support EPSRC's UK-RAS Network 10 research centers and laboratories in government financial term(As shown in Table 1)

TABLE 1. UK-RAS NETWORK 10 RESEARCH CENTERS AND LABORATORIES

\begin{tabular}{|c|c|c|c|c|c|}
\hline $\begin{array}{l}\text { Administration } \\
\text { Unit }\end{array}$ & Organization Name & \multicolumn{2}{|c|}{ OrganizationType } & \multirow{2}{*}{$\begin{array}{l}\text { Subject Field } \\
\text { Conducting robotics research of the highest } \\
\text { level and at generating disruptive } \\
\text { innovations in all areas related to robotics. }\end{array}$} & \multirow{2}{*}{$\begin{array}{l}\text { Region } \\
\text { London }\end{array}$} \\
\hline & $\begin{array}{l}\text { The Centre for Advanced } \\
\text { Robotics @ Queen Mary (ARQ), } \\
\text { Queen Mary University of } \\
\text { London }\end{array}$ & $\begin{array}{l}\text { University } \\
\text { Research } \\
\text { /Lab }\end{array}$ & Center & & \\
\hline & $\begin{array}{l}\text { Centre for } r \begin{array}{r}\text { Intelligent } \\
\text { Autonomous }\end{array} \text { Manufacturing } \\
\text { Systems, Queen's } \text { University } \\
\text { Belfast }\end{array}$ & $\begin{array}{l}\text { University } \\
\text { Research } \\
\text { /Lab }\end{array}$ & Center & $\begin{array}{l}\text { Multi-disciplinary research of } \\
\text { Electrical/Electronic/Mechanical/Aerospace } \\
\text { Engineering, Computer Science, Applied } \\
\text { Mathematics, Statistics, and Psychology. }\end{array}$ & Northern Ireland \\
\hline & $\begin{array}{l}\text { Edinburgh Centre for Robotics, } \\
\text { University of Edinburgh and } \\
\text { Heriot-Watt University }\end{array}$ & $\begin{array}{l}\text { University } \\
\text { Research } \\
\text { /Lab }\end{array}$ & Center & $\begin{array}{l}\text { Environment Interactions,Multi-Robot } \\
\text { Interactions, People Interactions, Self } \\
\text { Interactions, Enablers. }\end{array}$ & Edinburgh \\
\hline & $\begin{array}{l}\text { The Hamlyn Centre, Imperial } \\
\text { College London }\end{array}$ & $\begin{array}{l}\text { University } \\
\text { Research } \\
\text { /Lab }\end{array}$ & Center & $\begin{array}{l}\text { Medical robotics, Micro-machining and } \\
\text { fabrication equipment, Multi-material, } \\
\text { Precision 3D rapid prototyping,Fibre-optics } \\
\text { and ablation laser. }\end{array}$ & $\begin{array}{l}\text { Imperial College } \\
\text { London (South } \\
\text { Kensington } \\
\text { Campus) }\end{array}$ \\
\hline & $\begin{array}{l}\text { National Facility for Innovative } \\
\text { Robotic Systems, University of } \\
\text { Leeds }\end{array}$ & $\begin{array}{l}\text { University } \\
\text { Research } \\
\text { /Lab }\end{array}$ & Center & $\begin{array}{l}\text { Innovative robotics systems, Medical } \\
\text { surgical technique,Prosthetic fitting and } \\
\text { rehabilitation. }\end{array}$ & $\begin{array}{l}\text { West Yorkshire, } \\
\text { Leeds }\end{array}$ \\
\hline \multirow{5}{*}{$\begin{array}{l}\text { EPSRC } \\
\text { UK-RAS } \\
\text { Network }\end{array}$} & $\begin{array}{l}\text { Oxford Robotics Institute , } \\
\text { Department of Engineering } \\
\text { Science, University of Oxford }\end{array}$ & $\begin{array}{l}\text { University } \\
\text { Research } \\
\text { /Lab }\end{array}$ & Center & Mobile autonomy. & Oxford \\
\hline & $\begin{array}{l}\text { Centre for Autonomous Systems } \\
\text { Technology (CAST), Sheffield } \\
\text { Robotics and The University of } \\
\text { Liverpool }\end{array}$ & $\begin{array}{l}\text { University } \\
\text { Research } \\
\text { /Lab }\end{array}$ & Center & $\begin{array}{l}\text { Unmanned ground and air vehicles, } \\
\text { Biologically inspired robotics, Service } \\
\text { robotics, Societal research, Human-robot } \\
\text { interaction, Systems verification and safety, } \\
\text { Field robotics for outdoor and hazardous } \\
\text { environments. }\end{array}$ & Liverpool \\
\hline & $\begin{array}{l}\text { Autonomy USRG, University of } \\
\text { Southampton }\end{array}$ & $\begin{array}{l}\text { University } \\
\text { Research } \\
\text { /Lab }\end{array}$ & Center & $\begin{array}{l}\text { Big data,humanfactors, underwater or } \\
\text { high-altitude unmanned aerial vehicle. }\end{array}$ & Southampton \\
\hline & $\begin{array}{l}\text { UCL Engineering,THE } \\
\text { FACULTY OF ENGINEERING, } \\
\text { University College London }\end{array}$ & $\begin{array}{l}\text { University } \\
\text { Research } \\
\text { /Lab }\end{array}$ & Center & $\begin{array}{l}\text { Large scale robotic manufacturing, remote } \\
\text { inspection and making; Virtual Reality and } \\
\text { haptic interaction and tactile sensing; } \\
\text { Human scale tele-manipulation and robotic } \\
\text { surgery; Micro-nano robotic manipulation; } \\
\text { Robotic telepresence. }\end{array}$ & London \\
\hline & $\begin{array}{l}\text { International Manufacturing } \\
\text { Centre University of Warwick }\end{array}$ & $\begin{array}{l}\text { University } \\
\text { Research } \\
\text { /Lab }\end{array}$ & Center & $\begin{array}{l}\text { Hardware-in-the-loop, infotainment and } \\
\text { communication simulation, a multi-sensory } \\
\text { virtual environment, realworld environment } \\
\text { and modular autonomous systems } \\
\text { workbench. }\end{array}$ & Coventry \\
\hline
\end{tabular}


Training the next generation of world-class researchers in RAS is key to enhance the economic competitiveness of the UK. As part of the investment in robotics technologies from the UK government through the EPSRC, four Centers for Doctoral Training (CDTs) were established in Bristol, Edinburgh, Loughborough and Oxford (Table 2).

TABLE 2. UK-RAS NETWORK 4 CENTERS FOR DOCTORAL TRAINING (CDTS)

\begin{tabular}{|c|c|c|c|}
\hline Organization Name & Subject Field & Region & Organization Information \\
\hline $\begin{array}{l}\text { Bristol Robotics Laboratory, } \\
\text { EPSRC Centre for Doctoral } \\
\text { Training in Future Autonomous } \\
\text { and } \quad \text { Robotic } r \text { Systems } \\
\text { (FARSCOPE) }\end{array}$ & $\begin{array}{l}\text { Embedded intelligence, autonomous robot } \\
\text { systems, human-robot interaction, energy } \\
\text { autonomy, collective locomotion, tactile } \\
\text { sensors and haptic feedback systems, } \\
\text { motion tracking/positioning systems, } \\
\text { unmanned aerial vehicles, swarming } \\
\text { behavior, dependability, wearable and } \\
\text { pervasive systems, medical and } \\
\text { rehabilitation robotics, machine vision, } \\
\text { and bio-inspired architectures. }\end{array}$ & $\begin{array}{l}\text { University of the } \\
\text { West of England, } \\
\text { Frenchay campus, } \\
\text { Bristol }\end{array}$ & $\begin{array}{l}\text { BRL's interdisciplinary research team } \\
\text { focuses on key robotics features and } \\
\text { applications. The FARSCOPE CDT is } \\
\text { delivered jointly by the University of } \\
\text { Bristol and the University of the West of } \\
\text { England through their partnership, the } \\
\text { Bristol Robotics Laboratory. }\end{array}$ \\
\hline $\begin{array}{l}\text { Edinburgh Centre for Robotics, } \\
\text { (University of Edinburgh \& } \\
\text { Heriot-Watt University) EPSRC } \\
\text { Centre for Doctoral Training - } \\
\text { Edinburgh Centre for Robotics }\end{array}$ & $\begin{array}{l}\text { The Edinburgh Centre for Robotics } \\
\text { produces innovation ready postgraduates } \\
\text { equipped through technical preparation, } \\
\text { and cohort-wide training with scientific, } \\
\text { creative, ethical and enterprise skills, in } \\
\text { programmes supported by User partners } \\
\text { operating in RAS crucial market sectors } \\
\text { including oil and gas, defense, renewable } \\
\text { energy, healthcare, assisted living, } \\
\text { transport, space, automotive, } \\
\text { manufacturing, nuclear, digital media and } \\
\text { education. }\end{array}$ & $\begin{array}{l}\text { Heriot-Watt } \\
\text { University, } \\
\text { University } \\
\text { Edinburgh, } \\
\text { Edinburgh }\end{array}$ & $\begin{array}{l}\text { The goal of the CDT is to train } \\
\text { innovation-ready robotics researchers to } \\
\text { be part of a multi-disciplinary enterprise, } \\
\text { requiring sound knowledge of physics } \\
\text { (kinematics, dynamics), engineering } \\
\text { (control, signal processing, mechanical } \\
\text { design), computer science (algorithms for } \\
\text { perception, planning, decision making and } \\
\text { intelligent behavior, software } \\
\text { engineering), as well as allied areas } \\
\text { ranging from biology and biomechanics to } \\
\text { cognitive psychology. }\end{array}$ \\
\hline $\begin{array}{l}\text { Loughborough } \quad \text { University, } \\
\text { EPSRC Centre for Doctoral } \\
\text { Training in } \text { Embedded } \\
\text { Intelligence }\end{array}$ & $\begin{array}{l}\text { Embedded Intelligence is the integration } \\
\text { of intelligence into products, processes } \\
\text { and services so that (1) they work better } \\
\text { and (2) increase productivity, efficiency } \\
\text { and connectivity. Our cores areas of } \\
\text { expertise and interests are; autonomous } \\
\text { products, functional materials with high } \\
\text { performance connected systems, } \\
\text { data-to-knowledge solutions, and } \\
\text { engineering for industry, life and health. }\end{array}$ & $\begin{array}{l}\text { Loughborough, } \\
\text { Leicestershire }\end{array}$ & $\begin{array}{l}\text { The uniqueness of the CDT-EI resides on } \\
\text { the capability to innovatively address a } \\
\text { myriad of Embedded Intelligence } \\
\text { challenges posed by technical needs } \\
\text { ranging from the EI supply chain: the } \\
\text { design stage, through manufacturing of } \\
\text { embedded or on-bedded devices, to the } \\
\text { software behind data collection, as well as } \\
\text { integrative technologies, to finally the } \\
\text { requirements from end-users. }\end{array}$ \\
\hline $\begin{array}{l}\text { University of Oxford, EPSRC } \\
\text { Centre for Doctoral Training in } \\
\text { Autonomous Intelligent } \\
\text { Machines and Systems (AIMS) }\end{array}$ & $\begin{array}{l}\text { (1) Robotics, Vision and Perception; } \\
\text { (2) Machine Intelligence \& Multi-Agent } \\
\text { Systems; } \\
\text { (3) Control \& Verification; } \\
\text { (4) M2M, Secure Sensing \& Actuation. }\end{array}$ & $\begin{array}{l}\text { Department of } \\
\text { Engineering } \\
\text { Science,University } \\
\text { of Oxford, Oxford }\end{array}$ & $\begin{array}{l}\text { The aim of the CDT is to train a } \\
\text { world-class cohort of researchers in the } \\
\text { theory and practice of a new generation of } \\
\text { autonomous intelligent machines and } \\
\text { systems. The training programmer of the } \\
\text { CDT will provide a comprehensive, } \\
\text { state-of-the-art view to autonomous } \\
\text { intelligent systems; combining theoretical } \\
\text { foundations, systems research, academic } \\
\text { training and industry-initiated projects and } \\
\text { covering a range of topics aligned to four } \\
\text { key skills areas. }\end{array}$ \\
\hline
\end{tabular}

\section{UK-RAS DEVELOPMENT FRAMEWORK}

The UK government goal is to improve interactive, cognitive physical tools, automation and control of RAS. The priority research fields include perception and cognitive robotics, autonomous systems, healthcare and assistive robotics, service and vehicle robotics. The government will build on the UK's existing robotics and autonomous systems 
research and industrial capability to ensure that future growth and success is enabled across a broad range of core industrial sectors, such as aerospace, nuclear and automotive; in addition to enabling new capabilities in emerging cross-sectorial issues like demanding environments(See Figure 1)

From the application point of view, UK advanced robotics technique has tremendous developing space in national defense, medical treatment, manufacturing industry, transportation, entertainment and education. UK's leading technology can expand potential market in remote operation, disabled organ substitution and medical instruments. Firstly, UK-RAS characteristics focus on variety advantage technologies of UK, including materials science, electronics, telecommunications, digital media, artificial intelligence and software engineering. Secondly, UK-RAS Industrial Cluster has formed regional innovation ecosystem, and it has powerful networking opportunities and a complete set innovation facilities. It is easy for the public to get knowledge of guidance, finance, business management and training. Finally, small and medium enterprises (SMEs) are the core of UK-RAS revolution, and they are successful key for acquiring robots and autonomous systems assets, responding to challenges and resources.

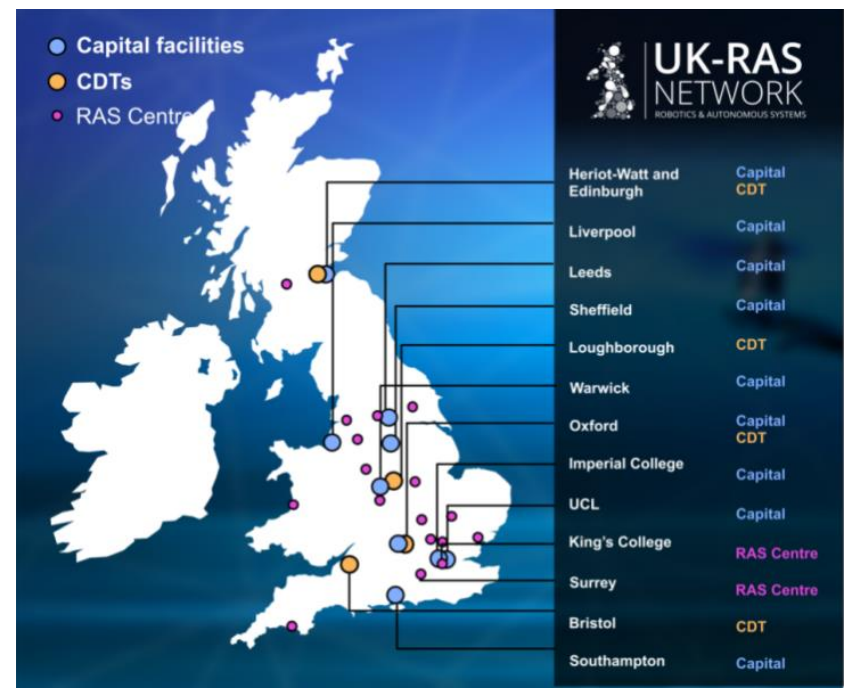

Fig 1. UK RAS R \& D research strategic distribution

\section{OPEN ISSUES AND SUGGESTIONS FOR UK-RAS FUTURE}

\section{DEVELOPMENT}

The industrial robot is irreplaceable important equipment in advanced manufacturing industry.In 2013, the Ministry of Industry and Information Technology of the People's Republic of China released 'Several Opinions of China's State Council on Promoting the Reform and Development of the Tourism Industry".It was proposed that a relatively complete industrial system of industrial robots should be formed in 2020, and 3-5 international competitiveness leading enterprises and 8-10 supporting industrial clusters should be resulted.By May 2015, the State Council issued "Made in China 2025", and the Chinese Government cleared and definited 9 strategic tasks and priorities, including high-end $\mathrm{CNC}$ machine tools and robotics [3]. In April 2016, "Robotics Industry Development
Plan (2016-2020)" has been issued by National Development and Reform Commission and Ministry of Finance [4].

In recent years, China has rapid growth in robotics industry and been recognized as world recognized manufacturing leading power. In 2015, China's industrial robotics market reached 66 thousand units, an increase of $16 \%$, and about $1 / 4$ of global sales.Under national science and technology program support, through long-term science and technology innovation, China has gradually mastered in advanced design and manufacturing methods of industrial robotics. Moreover, it completed scale application demonstration in automotive, electronics, logistics, transportation, sanitary products [5].

Although China's robotics industry was keeping in progressive, but there is a certain gap compared with international counterparts. There are some suggestions for China's RAS rapidly expanding:

- Lack of core key technologies and Independent innovation capability;

- Robotics industry has become increasingly homogeneous and low end of high-end industry phenomenon;

- The domestic market has been carved up by foreign enterprises; domestic robotics brand occupancy is relatively low;

- Strengthen research on robotics development strategy and create industrial development environment;

- Strengthen key technology research, attach importance to next technology generation and standards;

- Rapid development in service robotics industry;

- Enhance talent team construction in robot industry.

\section{CONCLUSION}

With rapidly development of robotics technology, robotics and autonomous system has been improved through increased automation and efficiency. Meanwhile, demand for robotics industrial applications and social services are becoming more important.The manufacturing industry requires a large number of industrial robots, intelligent machines and equipments to assist human beings engaged in complex and heavy labor; daily family life also requires a variety of intelligent robotics to help people engage in a wide variety services. With increasing maturity, RAS technology has entered a period of rapid development in 21 Century [6]. After 20 years of reforming and opening up, China's economy and technology has made considerable progress and development with grasping technology development conditions. For this purpose, RAS technology has been included in national medium and long-term science and technology development plan.

China's manufacturing capacity utilization in manufacturing cost advantages and high volume, encourage and support a number of large and medium-sized enterprises in the development of robotics industry. It will be possible to make China become a robotics $\mathrm{R} \& \mathrm{D}$ and manufacturing leading power, and promote social services, manufacturing 
industry, education, and entertainment industry to have advancement of science and technology. It will also drive industry development in information, communication, automation, electrical engineering, and manufacturing industry.

\section{REFERENCE}

[1] PWC report: "Future of Eight Core Technologies". Phoenix International Think http://pit.ifeng.com/a/20160918/49983199_0.shtml, 2016.9.18
[2] National Manufacturing Strategy Advisory Committee (NMSAC). China State Council. "Made in China 2025". Beijing Publishing House of Electronics Industry, 2016. (In Chinese)

[3] HegaoCai. Relfections on the Development of Robot Industry in China[J]. Journal of Integration Technology, 2015(5):1-4.

[4] Minghe Chen. The Problems and Countermeasures of the Development of the Robot Industry in China[J]. Science \& Technology for Development, 2015(6):768-774. (In Chinese)Rong Xiao. China

[5] Robotics Industry Present Situation, Issues and Countermeasures[J]. China Science and Technology Achievements, 2017, 18(3). (In Chinese)

[6] Dario Floreano, Claudio Mattiussi. Bio-Inspired Artificial Intelligence: Theories, Methods, and Technologies[M]. MIT Press, 2008.9.

[7] TauseefGulrez, Aboul Ella Hassanien. Advances in Robotics and Virtual Reality[M]. Springer, 2016. 